\title{
Workplace stress and its relation to cardiovascular disease risk factors among bus drivers in Egypt
}

Amira Mohsen ${ }^{1}$ and Sally Hakim ${ }^{2}$

${ }^{1}$ Department of Community Medicine, National Research Center, Cairo, Egypt. ${ }^{2}$ Department of Community Medicine, Environmental and Occupational Medicine, Faculty of Medicine, Ain Shams University, Cairo, Egypt (Correspondence to: S.A. Hakim: drsallyhakim7@gmail.com; dr_sallyhakim@ yahoo.com).

\begin{abstract}
Background: Driving buses exposes the drivers to many stressors that can increase their cardiovascular risk factors. Aims: The objective of this study was to measure the prevalence of workplace stress and its association with cardiovascular risk factors among bus drivers in Egypt.

Methods: A cross-sectional study was conducted on 234 bus drivers in Cairo, Egypt. Data were collected over a period of 6 months from August 2016 to January 2017. For all drivers, blood pressure, body weight and height and random blood sugar were measured. Professional driving duration/age ratio was calculated. Comparison between cardiovascular risk factors and workplace stress score was made. Unadjusted and adjusted odds ratios and 95\% confidence intervals were calculated using logistic regression models.

Results: A high prevalence of workplace stress (83.3\%) was observed among bus drivers. Moreover, a high prevalence of cardiovascular risk factors, particularly tobacco smoking (65.0\%), physical inactivity (93.6\%) and hypertension (33.3\%), was noted. After adjustment for age and other confounding factors, the risk factors associated with workplace stress were overweight/obesity and hypertension.

Conclusions: There is a positive association between workplace stress and some cardiovascular risk factors, such as hypertension and overweight/obesity, among bus drivers in Egypt.

Keywords: tobacco, cardiovascular risk, hypertension, occupational stress, prevalence.

Citation: Mohsen A; Hakim SA. Workplace stress and its relation to cardiovascular disease risk factors among bus drivers in Egypt. East Mediterr Health J. 2019;25(12):878-886. https://doi.org/10.26719/emhj.19.056

Received: 07/01/18; accepted: 20/05/18

Copyright (C) World Health Organization (WHO) 2019. Some rights reserved. This work is available under the CC BY-NC-SA 3.0 IGO license (https:// creativecommons.org/licenses/by-nc-sa/3.o/igo).
\end{abstract}

\section{Introduction}

Work stress is usually related to an occupational environment with high demands and little control in addition to low social support (1). All these factors are present in the daily working life of bus drivers. Bus or truck driving is considered one of the most stressful occupations and is associated with increased risk of chronic diseases, in particular, cardiovascular risk factors and diseases (2). Occupational risk factors to which professional drivers are exposed may be shift work, long working hours, loud noise, carbon monoxide and chemical materials that may lead to cardiovascular diseases (CVD). Also, bus drivers face stressors such as inadequate cabin ergonomics, violence from passengers, and traffic congestion (3). Bus drivers are more prone to daily behavioural risk factors such as obesity, poor irregular diets, and working while sitting for long periods of time (4). These factors when accompanied with job stress may worsen nonbehavioural risk factors such as blood pressure, lipid profile and diabetes, leading to a higher risk of cardiovascular events among professional drivers (5).

In Egypt, few studies have investigated the relationship between environmental hazards and
CVD. Negm et al. (6) found that different occupational environmental hazards might increase the incidence of coronary artery disease in young Egyptian male workers. In another study among Egyptian workers in a cigarette factory, the findings revealed that hypertension was the most prevalent stress-related disease (7). The Egyptian National Health Issues Survey in 2015 (8) showed that smoking was more prevalent in men, with $46 \%$ of men being current cigarette smokers, $34.3 \%$ were overweight and $26.4 \%$ were obese. The prevalence of hypertension among men aged $15-59$ years was $16.7 \%$ and this increased to $26.8 \%$ among men aged $35-59$ years. It is estimated that the prevalence of diabetes among Egyptians is around $15 \%$ among adults aged 20-70 years (9). The most common causes of death in Egypt are CVDs, mainly ischemic heart disease and cerebrovascular disease, which represent $46 \%$ of total deaths (10).

No research in Egypt has addressed both occupational and personal risk factors when investigating the association between occupational stress and CVD among bus drivers. Thus, the present study assessed the prevalence of workplace stress and its relation to CVD risk factors among bus drivers in Egypt. 


\section{Methods}

\section{Study design and population}

This was a cross-sectional study of 234 bus drivers who attended periodic medical examination at a health insurance hospital in Cairo, Egypt. Data were collected for a period of 6 months from August 2016 to January 2017.

\section{Sample size}

Sample size was calculated using Epi Info version 7. Hypertension was used as an indicator for CVD risk factors. The following assumptions were made: the prevalence of hypertension among bus drivers with low score of stress was $20 \%$ (as reported in the National Health Issues Survey of Egypt for a similar age group [8]); prevalence of hypertension for drivers with high stress was 40\% (11); $95 \%$ confidence interval (CI) and 90\% study power. Accordingly, a sample of 234 bus drivers was required. This number was taken out of a total of 420 bus drivers attending for annual medical examination at the health insurance hospital. All bus drivers attending the clinic every Tuesday (10-12 drivers) for 6 months were included until the required sample size was recruited.

\section{Tools and definition of variables}

Bus drivers were interviewed by a questionnaire that included items about sociodemographic factors, occupational characteristics, behavioural risk factors (smoking, low fruit/vegetable consumption and physical inactivity) and workplace stress. In addition, nonbehavioural risk factors as blood pressure, body mass index and random blood sugar were measured.

Two blood pressure readings were taken at an interval of 10-15 minutes. High blood pressure was defined as average systolic pressure $\geq 140 \mathrm{mmHg}$ or diastolic pressure $\geq 90 \mathrm{mmHg}$. Bus drivers were considered to have hypertension if they had been diagnosed previously by a medical professional and were taking antihypertensive drugs (8).

According to World Health Organization classification, individuals with body mass index (BMI) $\geq 25$ but $<30 \mathrm{~kg} / \mathrm{m}^{2}$ are considered to be overweight and those with BMI $\geq 30 \mathrm{~kg} / \mathrm{m}^{2}$ are considered to be obese (12). Hyperglycaemia is diagnosed by blood sugar level $\geq 200 \mathrm{mg} / \mathrm{dl}$ in a random test and the person has symptoms of diabetes (e.g., frequency of urination and thirst sensation). All bus drivers who had random blood sugar levels $\geq 200 \mathrm{mg} / \mathrm{dl}$ were recommended to seek medical advice for further diagnosis and follow-up. Bus drivers were considered to have diabetes if they had been diagnosed previously by a medical professional and were receiving medication (8).

Tobacco use included those who currently smoked any type of tobacco product daily (e.g., cigarettes, cigars or pipes). Low fruit and vegetable consumption was defined as consumption of $<5$ portions per day in a typical week (12). Low physical activity included those who practice $<150$ minutes per week of different physical activities (e.g., jogging, walking and cycling) and similar activities in a typical week, or those who practice $\leq 10$ minutes continuously of any type of physical activity per day (12).

The workplace stress survey questionnaire was composed by the American Institute of Stress (13). The survey consisted of 10 questions, and the answers ranged from 1 (strongly disagree) to 10 (strongly agree). If the total score was 10-30, the participant handled stress well; if the score was 40-60, the participant handled stress moderately well; and if the score was 70-100, the participant encountered problems that needed to be resolved.

We used an operational definition for social conflict in the form of a simple question. Persons who perceived any social problems (e.g., struggles/disagreements) with any family members (wife, children, parents or parentsin-law) or neighbours at least once per week were considered to have social conflict.

Professional driving duration and age ratio (PDAR) was calculated as follows: duration of professional driving divided by age (14). PDAR reflected the extent of professional driving experience. PDAR was coded into $\geq 0.5$ (more risk exposure) and $<0.5$ (less exposure $=$ reference).

\section{Ethical considerations}

All participants were informed about the study objectives and signed informed consent before participating in the study. Participant confidentiality was assured by having an anonymous questionnaire. Before conducting the study, the protocol was approved by the Research Ethics Committee of the Faculty of Medicine, Ain Shams University, Cairo, Egypt.

\section{Statistical analysis}

Descriptive analyses for all study variables were conducted. The $\chi^{2}$ test or Fisher's exact test was applied for bivariate analysis. Fisher's exact test was applied when any expected value in the $2 \times 2$ contingency table was < 5. Variables associated with work stress were included in the multiple binary logistic regression analysis to calculate the odds ratio (OR) and 95\% CI. All analyses were done using IBM-SPSS version 21. $P=0.05$ was considered significant.

\section{Results}

All the bus drivers were male. The mean age was $37.4 \pm$ 9.0 years and $>60 \%$ of them were aged $30-49$ years $(\mathrm{Ta}$ ble 1). Around two thirds were married and $61.1 \%$ achieved a low educational level. Social conflict reported was by $47 \%$. One quarter of the drivers had worked as professional drivers for $>20$ years while one fifth had a PDAR $\geq 0.5$. Around one third had reported $3-5$ during the past 12 months. Regarding behavioural risk factors, $65 \%$ of bus drivers were current smokers, only $6.4 \%$ regularly practiced physical exercise, and only around $9.0 \%$ ate $\geq$ 5 portions of fruits and vegetables per day. As for nonbehavioural risk factors, $61.5 \%$ of drivers were overweight or obese, one third experienced high blood pressure, 
Table 1 Sociodemographics, occupational characteristics, cardiovascular diseases risk factors and workplace stress among bus drivers

\section{Characteristics}

Age (years)

$<30$

$30-49$

$\geq 50$

Marital status

Married

Single

Divorced/widowed

Educational achievement

Low

Social conflicts

No

Working duration as drivers (years)

$<10$

$10-20$

PDAR

$<0.5$

$\geq 0.5$

Number of work accidents in last 12 months

None

1 or 2

3-5

Tobacco smoking

Non-smokers

Body mass index

Normal

Overweight

Obese

Blood pressure

Normal

High

Blood sugar

Normal

Hyperglycaemia

Portions of fruit/vegetables/day

$\geq 5$

$<5$

Physical exercise

Yes

Stress score classification

Handling well

Moderately well

Encountered problems

40

17.1

PDAR = professional driving duration and age ratio. 
and $8.1 \%$ had hyperglycaemia. Around $17 \%$ of bus drivers could handle stress well, $66.2 \%$ moderately well and $17.1 \%$ encountered problems.

Occupational stress was significantly associated with age, as the percentage of bus drivers aged $\geq 50$ years who encountered stress problems was $17.5 \%$ compared to none of those who handled stress well and $10.3 \%$ of those who handled stress moderately well (Table 2). The percentage of divorced/widowed drivers was higher among drivers who encountered stress problems compared to those who handled stress well or moderately well, but the difference was not significant. The percentage of those with low educational level (77.5\%) who encountered problems was significantly higher than the corresponding figure among those who handled stress well (28.2\%). The results revealed a strong association between social problems and workplace stress. Among those who encountered problems, the percentage of those working $>20$ years was significantly higher $(42.5 \%)$ than that among those who handled stress well (10.2\%). A significant association was found between PDAR and occupational stress score. There was an insignificant association between the number of accidents related to driving during the past year and occupational stress score.

There was an insignificant association between tobacco smoking and workplace stress (Table 3). The highest percentage of overweight/obesity (77.5\%) was observed among bus drivers who encountered problems, while the corresponding figures among drivers who handled stress well and moderately well was 53.8\% and 57.4\%, respectively. The relationship between physical activity, consumption of fruit/vegetables, hyperglycaemia and stress score was insignificant. The prevalence of high blood pressure among bus drivers who encountered problems was 4 times higher than the corresponding figure among drivers who handled stress well and around 1.5 times the figure among those who handled stress moderately well.

Table 2 Association between workplace stress score and sociodemographic and job characteristics

\begin{tabular}{|c|c|c|c|c|}
\hline \multirow[t]{2}{*}{ Characteristics } & \multicolumn{3}{|c|}{ Workplace stress score } & \multirow{2}{*}{$\begin{array}{c}\chi^{2} \text { test } \\
P\end{array}$} \\
\hline & $\begin{array}{l}\text { Handling well } \\
(\mathbf{n}=39) \\
\text { No. }(\%)\end{array}$ & $\begin{array}{c}\text { Moderately well } \\
(\mathbf{n}=155) \\
\text { No. }(\%)\end{array}$ & $\begin{array}{c}\text { Encountered } \\
\text { problems } \\
(\mathbf{n}=40) \\
\text { No. (\%) }\end{array}$ & \\
\hline \multicolumn{5}{|l|}{ Age (years) } \\
\hline$<30$ & $18(46.2)$ & $45(29.0)$ & $5(12.5)$ & 14.822 \\
\hline $30-49$ & $21(53.8)$ & $94(60.7)$ & $28(70.0)$ & 0.005 \\
\hline$\geq 50$ & $0(0.0)$ & $16(10.3)$ & $7(17.5)$ & \\
\hline \multicolumn{5}{|l|}{ Marital status } \\
\hline Married & $31(79.5)$ & $101(65.2)$ & $23(57.5)$ & 7.242 \\
\hline Single & $3(11.5)$ & $20(12.9)$ & $3(7.5)$ & 0.124 \\
\hline Others $^{a}$ & $5(9.4)$ & $34(21.9)$ & $14(35.0)$ & \\
\hline \multicolumn{5}{|c|}{ Educational achievement } \\
\hline Low & $11(28.2)$ & $101(65.2)$ & $31(77.5)$ & 23.360 \\
\hline High & $28(71.9)$ & $54(34.8)$ & $9(22.5)$ & $<0.001$ \\
\hline \multicolumn{5}{|l|}{ Social conflicts } \\
\hline No & $36(92.3)$ & $78(50.3)$ & $10(25.0)$ & 37.225 \\
\hline Yes & $3(7.7)$ & $77(49.7)$ & $30(75.0)$ & $<0.001$ \\
\hline \multicolumn{5}{|c|}{ Professional driving duration (years) } \\
\hline$<10$ & $20(51.3)$ & $57(36.7)$ & $7(17.5)$ & 14.623 \\
\hline $10-20$ & $15(38.5)$ & $60(38.8)$ & $16(40.0)$ & 0.006 \\
\hline$>20$ & $4(10.2)$ & $38(24.5)$ & $17(42.5)$ & \\
\hline \multicolumn{5}{|l|}{ PDAR } \\
\hline$<0.5$ & $35(89.7)$ & $130(83.9)$ & $25(62.5)$ & 11.750 \\
\hline$\geq 0.5$ & $4(10.3)$ & $25(16.1)$ & $15(37.5)$ & 0.003 \\
\hline \multicolumn{5}{|c|}{ No. of work accidents (last 12 months) } \\
\hline No & $18(46.2)$ & $39(25.2)$ & $10(25.0)$ & 7.058 \\
\hline 1 or 2 & $11(28.2)$ & $60(38.7)$ & $16(40.0)$ & 0.133 \\
\hline $3-5$ times & $10(52.6)$ & $56(36.1)$ & $14(35.0)$ & \\
\hline
\end{tabular}

Divorced or widowed.

PDAR = professional driving duration and age ratio. 


\begin{tabular}{|c|c|c|c|c|}
\hline \multirow[t]{2}{*}{ Characteristics } & \multicolumn{3}{|c|}{ Workplace stress score } & \multirow{2}{*}{$\begin{array}{c}\chi_{2} \text { test /Fisher's exact test } \\
\mathbf{P}\end{array}$} \\
\hline & $\begin{array}{l}\text { Handling } \\
\text { well }\end{array}$ & $\begin{array}{c}\text { Handling } \\
\text { moderately } \\
\text { well }\end{array}$ & $\begin{array}{l}\text { Encountered } \\
\text { problems }\end{array}$ & \\
\hline \multicolumn{5}{|l|}{ Smoking } \\
\hline Non-smokers & $17(43.6)$ & $53(34.2)$ & $12(30.0)$ & $\chi 2=1.748$ \\
\hline Smokers & $22(56.4)$ & $102(65.8)$ & $28(70.0)$ & $P=0.417$ \\
\hline \multicolumn{5}{|l|}{ Body mass index } \\
\hline Normal & $18(46.2)$ & $66(42.6)$ & $9(22.5)$ & $\chi^{2}=6.157$ \\
\hline Overweight/ obese & $21(53.8)$ & $75(57.4)$ & $15(77.5)$ & $P=0.046$ \\
\hline \multicolumn{5}{|c|}{ Portions of fruit/vegetables/day } \\
\hline$\geq 5$ & $7(17.9)$ & $14(9.0)$ & $1(2.5)$ & Fisher's exact test $=5.265$ \\
\hline$<5$ & $32(82.1)$ & 141 (91.o) & $39(97.5)$ & $P=0.079$ \\
\hline \multicolumn{5}{|c|}{ Regular physical exercise } \\
\hline Yes & $5(12.8)$ & $9(5.8)$ & $1(2.5)$ & Fisher's exact test $=3.346$ \\
\hline No & $34(87.2)$ & $146(94.2)$ & 39 (97.5) & $P=0.209$ \\
\hline \multicolumn{5}{|l|}{ High blood pressure } \\
\hline No & $34(87.2)$ & $102(65.8)$ & $20(50.0)$ & $\chi^{2}=12.436$ \\
\hline Yes & $5(12.8)$ & $53(34.2)$ & $20(50.0)$ & $P=0.002$ \\
\hline \multicolumn{5}{|l|}{ Hyperglycaemia } \\
\hline No & $37(94.9)$ & $143(92.3)$ & $35(87.5)$ & Fisher's exact test $=1.491$ \\
\hline Yes & $2(5.1)$ & $12(7.7)$ & $5(12.5)$ & $P=0.520$ \\
\hline
\end{tabular}

After adjustment for age and other occupational confounding variables and considering bus drivers who handled stress well as the reference group, the following results were obtained (Table 4). Only bus drivers who encountered stress problems were more prone to be overweight or obese. The prevalence of high blood pressure was strongly associated with workplace stress. Bus drivers who handled stress moderately well were around 4 times more likely to have high blood pressure, while those who encountered stress problems were nearly 16 times more likely.

\section{Discussion}

In this study over $80 \%$ of the bus drivers showed varying degrees of workplace stress. In comparison to other studies, lower rates of moderate to high stress were reported among city bus drivers in the Islamic Republic of Iran (74.5\%), Mumbai, India (66.2\%), and Colombia (40.5\%) (15-17). Bus drivers who encountered stress problems in the present study were characterized by being older, having lower educational achievement, facing more social conflicts and having more experience in driving (> 10 years and PDAR $\geq 0.5$ ). Similar findings were reported by Biglari et al. (15) but other studies reported greater strains among younger drivers and those with $<10$ years of driving experience (18). The controversial age-related differences in stress may be down to which age groups cope with the problems faced during driving, which depends on how bus drivers use job controls to buffer the effect of excessive job demands that result in workplace stress (19).

We found more reported accidents during the past 12 months (3 of 4 ) among bus drivers with high stress scores. Other studies have reported a positive association between occupational stress/strain and number of accidents $(16,17)$. Workplace stress and unsafe driving behaviour are among the most important factors associated with the occurrence of work-related accidents among bus drivers (20). Social conflict was markedly high among bus drivers with high stress scores. The combined effect of workplace stress and social problems of bus drivers could explain the high percentage of reported accidents among those with stress problems. The methodology of our study could not explain the cause of the complex association between workplace stress, social conflicts and road accidents.

Regarding behavioural risk factors, we revealed that the majority of participants did not practice any regular physical activities. However, our results showed an insignificant association between workplace stress and physical inactivity. Previous studies using prospective data revealed that job stress is strongly associated with higher risk of physical inactivity (21-23).

Our findings revealed low daily consumption of fruit and vegetables (i.e., < 5 portions per day) particularly among bus drivers who encountered stress problems (97.5\%). Low consumption of fruit and vegetables was common among Egyptian adults (94.6\%) (24). Similar results were reported among bus drivers in Brazil (25), whereas French et al. (26) reported high consumptions of 


\begin{tabular}{|c|c|c|c|}
\hline \multirow[t]{2}{*}{ Variables } & \multicolumn{3}{|c|}{ Workplace stress score } \\
\hline & Handling well ${ }^{\mathrm{a}}$ & Handling moderately well & Encountered problems \\
\hline \multicolumn{4}{|l|}{ Overweight/obesity } \\
\hline $\begin{array}{l}\text { Unadjusted OR } \\
\text { (95\% CI) }\end{array}$ & $\begin{array}{l}1 \\
-\end{array}$ & $\begin{array}{c}1.56 \\
(0.57-2.34)\end{array}$ & $\begin{array}{c}2.95 \\
(1.12-7.81)\end{array}$ \\
\hline $\begin{array}{l}\text { Adjusted OR } \\
(95 \% \mathrm{CI})^{\mathrm{b}}\end{array}$ & $\begin{array}{l}1 \\
-\end{array}$ & $\begin{array}{c}1.83 \\
(0.84-3.96)\end{array}$ & $\begin{array}{c}6.16 \\
(2.06-18.38)\end{array}$ \\
\hline \multicolumn{4}{|l|}{ High blood pressure } \\
\hline $\begin{array}{l}\text { Unadjusted OR } \\
\text { (95\% CI) }\end{array}$ & $\begin{array}{l}1 \\
-\end{array}$ & $\begin{array}{c}3.53 \\
(1.31-9.56)\end{array}$ & $\begin{array}{c}6.80 \\
(2.21-20.94)\end{array}$ \\
\hline $\begin{array}{l}\text { Adjusted OR }{ }^{\mathrm{b}} \\
(95 \% \mathrm{CI})\end{array}$ & 1 & $\begin{array}{c}3.68 \\
(1.29-10.50)\end{array}$ & $\begin{array}{c}15.92 \\
(4.35-58.31)\end{array}$ \\
\hline
\end{tabular}

${ }^{a}$ Reference group.

${ }^{b}$ Adjusted for age, social conflict, educational level and driving duration and professional driving duration and age ratio.

fruit and vegetables among transit workers in the United States of America.

As for nonbehavioural factors, it was found that $61.5 \%$ of bus drivers were overweight or obese, which is similar to the national figure (60.7\%) (8) in adult Egyptians. There was a significant association between workplace stress and BMI such that bus drivers with high stress scores were more prone to be overweight/obese, even after adjustment for other confounding variables. Our results are in agreement with other studies (14,22,23-25). Prolonged sitting and long daily duty hours, physical inactivity, lack of break times, and unhealthy diet are among the risk factors associated with overweight/ obesity.

Our results showed a lower prevalence of diagnosed hyperglycaemia $(8.1 \%)$ among bus drivers than the estimated national figure $14.2 \%$ (27). However, the association between workplacestress and hyperglycaemia (diabetes) was insignificant. In agreement with our findings, Sui et al. (28) reported no association between occupational stress and risk of diabetes, while other studies confirmed such an association $(22,29)$. Job stress may disturb glucose metabolism, which in turn increases the risk of diabetes directly, or indirectly through its effects on lifestyle, for example, obesity and physical inactivity $(21,30)$.

Our results revealed that one third of participants had high blood pressure, which is higher than the national figure (26.8\%) (8), and there was a significant association between workplace stress and high blood pressure, even after adjustment for other confounding factors. This finding was similar to others studies $(11,16,31,32)$. The reason why there has been a high prevalence of high blood pressure in the current work may be related to higher percentages of lifestyle risk factors among study participants. Moreover, workplace stress is associated with increased thickness of the arterial intima media, which is found in men but not women, and this could explain the link between stress and hypertension (33).

The current work showed that two thirds of bus drivers were current smokers, which exceeds the national figure $(46.4 \%)$ (8). However, the relationship between occupational stress and smoking was insignificant. This finding is similar to the studies of Biglari et al. (15) and Kouvonen et al. (34), but contrary to those of Nyberg et al. (22) and Cunradi et al. (35) who reported a positive association. The relationship between occupational stress and smoking could be explained by the fact that bus drivers feel it is a way to relieve tension (36) or as a result of neuroendocrine elevations associated with this stressful occupation.

The present study had some limitations. This was a cross-sectional study with the inherent limitation of not being able to determine the causal relationship between workplace stress and cardiovascular risk factors. Also, in this study we did not measure the lipid profile of bus drivers and this is considered to be one of the important cardiovascular risk factors. Furthermore, some cardiovascular risk factors, such as exercise, smoking, and fruit and vegetable consumption, were assessed by self-reporting. The study included only a sample of bus drivers that was not representative of all professional bus drivers in Cairo. Therefore, we recommend larger studies on all professional bus drivers in Cairo with full investigations of all cardiovascular risk factors.

In conclusion, the current study revealed high prevalence of workplace stress among bus drivers. The final adjusted model of logistic regression analysis included only high blood pressure and overweight/ obesity as independent cardiovascular risk factors associated with workplace stress. Accordingly, we recommend implementing a tailored risk management approach that focuses on hypertension and weight reduction for bus drivers who encounter stress problems.

Funding: None.

Competing interests: None declared. 


\section{Évaluation du stress au travail et de sa relation avec les facteurs de risque de maladies cardio-vasculaires dans un échantillon de conducteurs de bus en Égypte \\ Résumé}

Contexte : La conduite de bus expose les conducteurs à de nombreux éléments stressants qui augmentent les facteurs de risque cardio-vasculaire.

Objectif : La présente étude avait pour objectif de mesurer la prévalence du stress au travail et son association avec les facteurs de risque des maladies cardio-vasculaires chez les conducteurs de bus en Égypte.

Méthodes : Une étude transversale a été menée auprès de 234 conducteurs de bus au Caire (Égypte). Les données ont été recueillies sur une période de six mois, d'août 2016 à janvier 2017. La tension artérielle, le poids, la taille et la glycémie aléatoire ont été mesurés pour tous les conducteurs de l'étude. Le ratio durée/âge de conduite professionnelle a été calculé. Une comparaison entre les facteurs de risque cardio-vasculaire et le score de stress en milieu de travail a été établie. Les odds ratios non ajustés et ajustés et les intervalles de confiance à $95 \%$ ont été calculés à l'aide de modèles de régression logistique.

Résultats : Une forte prévalence du stress au travail (83,3\%) a été constatée chez les conducteurs de bus. De plus, une prévalence élevée de facteurs de risque cardio-vasculaire, notamment le tabagisme (65,0\%), la sédentarité (93,6 \%) et l'hypertension (33,3\%) a été observée. Après ajustement en fonction de l'âge et d'autres facteurs de confusion, les facteurs de risque associés au stress en milieu de travail étaient le surpoids ou l'obésité et l'hypertension.

Conclusion : Il existe une association positive entre le stress en milieu de travail et un certain nombre de facteurs de risque cardio-vasculaire chez les conducteurs de bus en Égypte, notamment l'hypertension et le surpoids ou l'obésité.

$$
\begin{aligned}
& \text { تقييم إجهاد العمل وعالاقته بعو امل خطر الإصابة بأمراضى القلب والأوعية الدموية لدى عينة من سائقي الحافلات } \\
& \text { في مصر } \\
& \text { أميرة محسن، سالي حكيم } \\
& \text { الخالاصنة } \\
& \text { الخلفية: قيادة الحافلات تُعِّض السائقين لكثير من الضغوط التي تزيد من عوامل تعرضهم لخطر الإصابة بأمراض القلب والأوعية الدموية. } \\
& \text { الأهداف: هدفت هذه الدراسة إلى قياس معدل انتشار إجهاد العمل، ومدى ارتباطه بعو امل خطر الإصابة بأمراض القلب والأوعية الدموية. }
\end{aligned}
$$

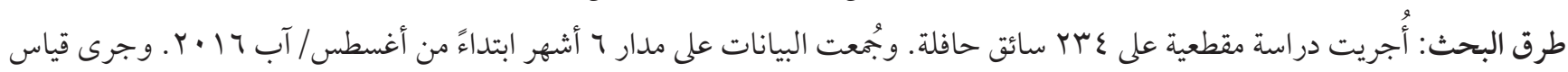

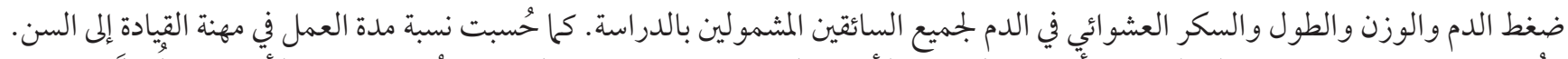

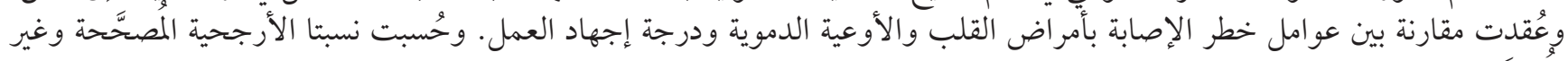

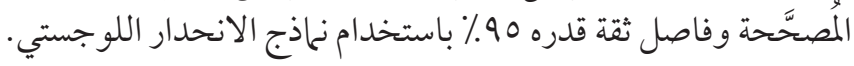

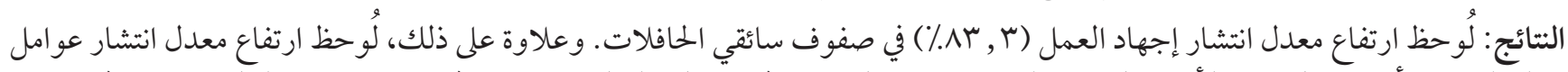

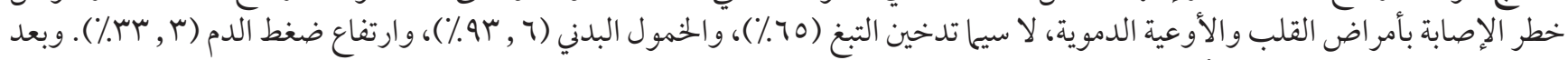

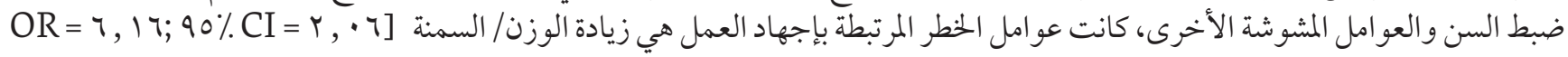

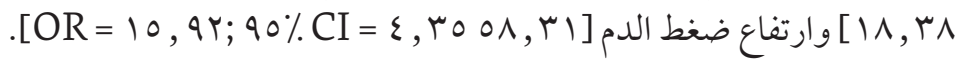

$$
\begin{aligned}
& \text { الاستنتاج: يوجد ارتباط إيجابي بين إجهاد العمل وعدد من عو امل خطر الإصابة بأمراض القلب والأوعية الدموية، مثل ارتفاع ضغط الدم وزيادة } \\
& \text { الوزن أو السمنة. }
\end{aligned}
$$

\section{References}

1. Byrne DG and Espnes GA. Occupational stress and cardiovascular disease. Stress Health. 2008;24:231-8. http://dx.doi. org/10.1002/smi.1203

2. Thiese MS, Moffitt G, Hanowski RJ, Kales SN, Porter RJ, Hegmann KT. Commercial driver medical examinations: prevalence of obesity and comorbidities and certification outcomes. J Occup Environ Med. 2015 Jun;57(6):659-65. http://dx.doi.org/10.1097/ JOM.0000000000000422 PMID:25710607

3. Tse JL, Flin R, Mearns K. Bus driver well-being review: 50 years of research. Transp Res F Traffic Psychol Behav. 2006 Mar;9(2):89-114. https://doi.org/10.1016/j.trf.2005.10.002

4. Robinson CF, Burnett CA. Truck drivers and heart disease in the United States, 1979-1990. Am J Ind Med. 2005 Feb;47(2):113-9. http://dx.doi.org/10.1002/ajim.20126 PMID:15662648 
5. Lee NS, Lee KJ, Kim JJ, Lee JW. The relationship between job stress and dyslipidemia in express bus drivers. Korean J Occup Environ Med. 2010 Sep;22(3):221-9. https://doi.org/10.35371/kjoem.2010.22.3.221

6. Negm H, Fayez M, El-Mahdy N, Youssef A. Effects of working environment on ischemic heart disease burden profile in young Egyptian males. Egypt J Occup Med 2013;37(2):195-216.

7. Zaghloul A, Ananian F, Siha M. The impact of work and family stress on workers health. Br J Appl Sci Technol. 2014;4(12):1869-81.

8. Egypt Health Issues Survey 2015. Cairo: Ministry of Health and Population; Rockville, MD: ICF International (https://dhsprogram.com/publications/publication-fr313-dhs-final-reports.cfm, accessed 18 June 2019).

9. Hegazi R, El-Gamal M, Abdel-Hady N, Hamdy O. Epidemiology of and risk factors for type 2 diabetes in Egypt. Ann Glob Health. 2015 Nov-Dec;81(6):814-20. http://dx.doi.org/10.1016/j.aogh.2015.12.011 PMID:27108148:

10. Turk-Adawi K, Sarrafzadegan N, Fadhil I, Taubert K, Sadeghi M, Wenger NK, et al. Cardiovascular disease in the Eastern Mediterranean region: epidemiology and risk factor burden. Nat Rev Cardiol. 2018 Feb;15(2):106-19. http://dx.doi.org/10.1038/ nrcardio.2017.138 PMID:28933782

11. Owolabi AO, Owolabi MO, OlaOlorun AD, Olofin A. Work-related stress perception and hypertension amongst health workers of a mission hospital in Oyo State, south-western Nigeria. Afr J Prm Health Care Fam Med. 2012;4(1):307. http://dx.doi.org/10.4102/ phcfm.v4i1.307

12. The WHO STEPwise approach to non-communicable disease risk factor surveillance. WHO STEPS Surveillance Manual. World Health Organization; 2017 (https://www.who.int/ncds/surveillance/steps/STEPS_Manual.pdf?ua=1, accessed 26 June 2019 ).

13. Workplace stress survey. Weatherford, TX: American Institute of Stress (https://www.stress.org/wp-content/ uploads/2011/08/ Workplace-Stress-Survey.pdf, accessed 18 June 2019).

14. Shin SY, Lee CG, Song HS, Kim HS, Lee HS, Jung MS, et al. Cardiovascular Disease Risk of Bus Drivers in a City of Korea. Ann Occup Environ Med. 2013 Nov 11;25(1):34. http://dx.doi.org/10.1186/2052-4374-25-34 PMID:24472511

15. Biglari H, Ebrahimi MH, Salehi M, Poursadeghryan M, Ahmadnezhad I, Abbasi M. Relationship between occupational stress and cardiovascular diseases risk factors in drivers. Int J Occup Med Environ Health. 2016 Nov 18;29(6):895-901. http://dx.doi. org/10.13075/ijomeh.1896.00125 PMID:27869240

16. Taklikar CS. Occupational stress and its associated health disorders among bus drivers. Int J Commun Med Public Health. 2016;3(1):208-11. http://dx.doi.org/10.18203/2394-6040.ijcmph20151564

17. Useche SA, Alonso F, Cendales BE, Autukeviciute R, Serge A. Burnout, Job strain and road accidents in the field of public transportation: the case of city bus drivers. J Environ Occup Sci. 2017;6(1):1-7. http://dx.doi.org/10.5455/jeos.20170202074636

18. Hlotova Y and Cats O. Measuring bus driver's occupational stress under changing working conditions. Transp Res Record. 2014; 2415:13-20. https://doi.org/10.3141/2415-02

19. Shultz KS, Wang M, Crimmins EM, Fisher GG. Age differences in demand-control model of work stress. An examination of data from 15 European countries. J Appl Gerontol. 2010 Feb;29(1):21-47. http://dx.doi.org/10.1177/0733464809334286 PMID:20948986

20. Kontogiannis, T. Patterns of driver stress and coping strategies in a Greek sample and their relationship to aberrant behaviors and traffic accidents. Accid Anal Prev. 2006 Sep;38(5):913-24. http://dx.doi.org/10.1016/j.aap.2006.03.002 PMID:16620741

21. Fransson EI, Heikkila K, Nyberg ST, Zins M, Westerlund H, Westerholm P, et al. Job strain as a risk factor for leisure-time physical inactivity: an individual- participant meta-analysis of up to 170,000 men and women: the IPD-Work Consortium. Am J Epidemiol. 2012 Dec 15;176(12):1078-89. http://dx.doi.org/10.1093/aje/kws336 PMID:23144364

22. Nyberg ST, Fransson EI, Heikkila K, Alfredsson L, Casini A, Clays E, et al. Job strain and cardiovascular disease risk factors: MetaAnalysis of individual-participant data from 47,000 men and women. Plos One. 2012 Jun 20;8(6):e67323. http://dx.doi.org/10.1371/ journal.pone.0067323 PMID:23840664

23. Oshio T, Tsutsumi A, Inoue A. The association between job stress and leisure-time physical inactivity adjusted for individual attributes: evidence from Japanese occupational cohort survey. Scand J Work Environ Health. 2016May 1;42(3):228-36. http:// dx.doi.org/10.5271/sjweh.3555 PMID:26913937

24. Egypt STEPS survey 2011-2012. Fact Sheet. available at: http://www.who.int/ncds/surveillance/steps/2011-2012_Egypt_FactSheet. pdf. Accessed 21 January 2019

25. Balieiro LC, Rossato LT, Waterhouse J, Paim SL, Mota MC, Crispim CA. Nutritional status and eating habits of bus drivers during the day and night. Chronobiol Int. 2014 Dec;31(10):1123-9. http://dx.doi.org/10.3109/07420528.2014.957299 PMID:25231504

26. French SA, Harnack LG, Toomey TL and Hannan PJ. Association between body weight, physical activity and food choices among metropolitan transit workers. Int J Behav Nutr Phys Act. 2007 Nov 2;4:52. http://dx.doi.org/10.1186/1479-5868-4-52 PMID:17980026

27. World Health Organization: diabetes country profiles 2016. Egypt (http://www.who.int/diabetes/country-profiles/egy_en.pdf, accessed 18 June 2019).

28. Sui H, Sun N, Zhan L, Lu X, Chen T, Mao X. Association between work-related stress and risk of type 2 diabetes: a systematic review and meta-analysis of prospective cohort studies. PLoS One 2016 Aug 11;11(8):e0159978. http://dx.doi.org/10.1371/journal. pone.0159978 PMID:27513574 
29. Nyberg ST, Fransson EI, Heikkila“ K, Ahola K, Alfredsson L, Bjorner JB, et al. Job strain as a risk factors for type 2 diabetes: a pooled analysis of 124,808 men and women. Diabetes Care. 2014 Aug;37(8):2286-75. http://dx.doi.org/10.2337/dc13-2936 PMID:25061139

30. Heikkilä K, Fransson EI, Nyberg ST, Zins M, Westerlund H, Westerholm P, et al. Job strain and health-related lifestyle: findings from an individual participant meta-analysis of 118000 working adults. Am J Public Health. 2013 Nov;103(11):2090-97. http://dx. doi.org/10.2105/AJPH.2012.301090 PMID:23678931

31. Rosenthal T, Alter A. Occupational stress and hypertension. J Am Soc Hypertens. 2012 Jan-Feb;6(1):2-22. http://dx.doi. org/10.1016/j.jash.2011.09.002 PMID:22024667

32. Landsbergis PA, Dobson M, Koutsouras G, Schnall P. Job strain and ambulatory blood pressure: a meta-analysis and systematic review. Am J Public Health. 2013 Mar;103(3):e61-71. http://dx.doi.org/10.2105/AJPH.2012.301153 PMID:23327240

33. Hintsanen M, Kivimäki M, Elovainio M, Pulkki-Råback L, Keskivaara P, Juonala M, et al. Job strain and early atherosclerosis: The Cardiovascular Risk in Young Finns study. Psychosom Med. 2005 Sep-Oct;67(5):740-7. http://dx.doi.org/10.1097/01. psy.0000181271.04169.93 PMID:16204432

34. Kouvonen A, Kivimaki M, Pentti J, Vahtera J. Work stress, smoking status and smoking intensity: an observational study of 41690 employees. J Epidemiol Community Public Health. 2005 Jan;59(1):63-9. http://dx.doi.org/10.1136/jech.2004.019752 PMID:15598729

35. Cunradi CB, Lipton R, Banerjee A. Occupational correlates of smoking among urban transit operators: a prospective study. Subst Abuse Treat Prev Policy. 2007 Dec 20;2:36. http://dx.doi.org/10.1186/1747-597X-2-36 PMID:18096082

36. Goon S, Bipasha MS. Prevalence and pattern of smoking among bus drivers of Dhaka, Bangladesh. Tob Use Insights. 2014 Mar 9;7:21-5. http://dx.doi.org/10.4137/TUI.S13966 PMID:25741182 